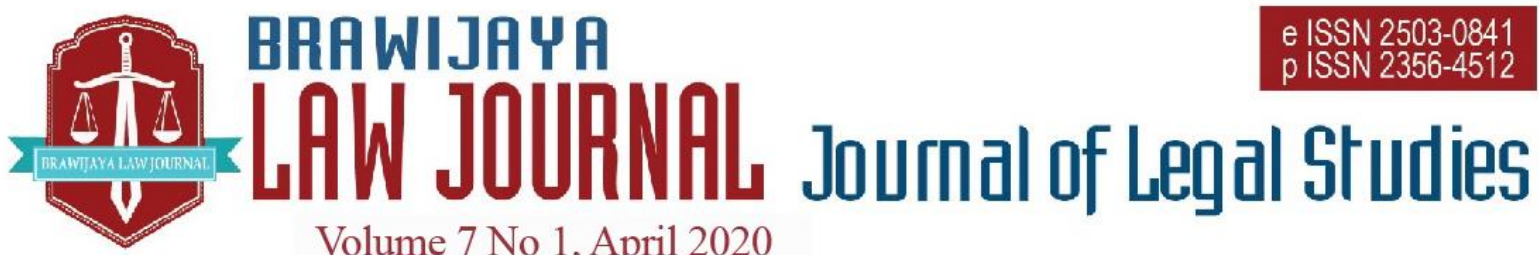

Volume 7 No 1, April 2020

Nationally Accredited No. 30/E/KPT/2018 Dated 24th October 2018

This work is licensed under a Creative Commons Attribution-NonCommercial 4.0 International License

\title{
Gashb and Itlaf Arrangements in KHES and Authority of Justice (Review of Chapter XV of Book II of KHES)
}

\author{
Sufiarina $^{\text {a }}$, Herman Sudrajat ${ }^{\mathrm{b}}$, Hamidullah Mahmud ${ }^{\mathrm{c}}$ \\ ${ }^{a}$ Faculty of Law, Universitas Tama Jagakarsa \\ Email: sufiarina@jagakarsa.ac.id \\ ${ }^{\mathrm{b}}$ Advocate and graduate of Universitas Tama Jagakarsa \\ Email: manzat1609@yahoo.co.id \\ ${ }^{c}$ UIN Syarif Hidayatullah \\ Email: hamidjakarta@gmail.com
}

Submitted : 2019-08-12 | Accepted : 2020-04-13

\begin{abstract}
As a guide for judges in the Religious Court, the Supreme Court has issued Perma No. 2 of 2008 concerning the Compilation of Sharia Economic Law (KHES). It contained Gashb and Itlaf, in Book II about the Covenant, whereas Gashb and Itlaf have interpreted as deprivation and destruction. Briefly, Gashb and Itlaf seem to be an offence because of the phrase taking or destroying someone else's property. Offence in the field of Islamic economics is the absolute authority of the State Court. For this reason, it is necessary to examine whether Gashb and Itlaf included in the context of Islamic economics. It also needs to be examined whether Gashb and Itlaf are the absolute authority of the Religious Court.

Normative juridical research carried out by discussing Book II of KHES, specifically Chapter XV. It then analysed with the absolute competence of the Religious court, the provisions of Article 49 of the Law of Religious Court. The analysis complemented by a study of legal principles in Islamic economics. Comparisons also made with the concepts of legal relations in the Civil Code, especially regarding the binding and offence in the Criminal Code.

The research results of Gashb and Itlaf do not originate from the contract and do not include business activities with Islamic economic principles. Thus Gashb and Itlaf are not included in the absolute authority of the Religious Court. Gashb and Itlaf are not intended as offences because the sanctions are compensation claims. Claims are filed based on lawsuits that violate the law and become the absolute authority of the State Court. Placement of Gashb and Itlaf in KHES is wrong because it does not include Islamic economic activities, so it must have removed from KHES.
\end{abstract}

Keywords: sharia economics; contracts; Gashb and Itlaf; the authority of religious courts.

\section{INTRODUCTION}

Law No. 7 of 1989 regarding Religious

Court was amended by Law No. 3 of 2006 and the second amendment to Law No. 50 of
2009 concerning Religious Court (from now on abbreviated as UU-PA). Religious Court is one of the actors of judicial power for Muslim people seeking justice regarding 
some instances. Some instances, as the absolute authority of religious court, are stated in Article 49 of Law No. 3 of 2006 from letter (a) until letter (i). Article 49 letter (i) Law No. 3 of 2006 establishes Islamic economics as the absolute authority of the Religious Court. The elucidation of Article 49 of the UU-PA directly dives into the settlement of the sharia economy, which is interpreted as a dispute, even though the authority of the Religious Court is not only sharia economy. Besides, the explanation of Article 49 of the UU-PA also narrows the authority of the Religious Court because it declares as a "dispute resolution."

Disputes interpreted as disputes over individual interests in the sense of being in the realm of civilization. If a dispute cannot be resolve by amicable agreement, a forced effort can be sought through legal means by filing a claim in the form of a lawsuit. The claim is filed with the competent court to obtain a judge's decision related to the truth of the plaintiff's right in his legal relationship with the defendant.

Peter Mahmud Marzuki said that it was essential to know the nature of legal connections to understand the legal regime that controlled the legal relations. Furthermore, legal relations will determine which court has the authority to resolve disputes. ${ }^{1}$ The established legal relationship needs to be known to determine legal steps in filing litigation claims in court. According to Retnowulan Sutantio, ${ }^{2}$ interests are civil rights and obligations regulated in material civil law.

Material law for Islamic economics found among others in the UU-PA, Law No. 19 of 2008 concerning State Sharia Securities

Peter Mahmud Marzuki, Pengantar Ilmu Hukum, (Kencana Prenada Media Grup, Jakarta 2009), 255 .

2 Retnowulan Sutantio dan Iskandar Oeripkartawinata, Hukum Acara Perdata Teori dan Praktek, (Mandar Maju Publishing, $9^{\text {th }}$ Ed, 2002), 1

3 Domiri, 'Analisis Tentang Sistem Peradilan Agama di Indonesia', (2016) 47(43) Jurnal Hukum dan Pembangunan, 334, (ISSN: 0125-9687 (Print) E-ISSN: 2503-1465 (Online))

4 Elucidation of Article 49; Dispute resolution is not only limited in the field of sharia banking but also and Law No. 21 of 2008 concerning Islamic Banking as well as in KHES. The publication of KHES based as a guideline for judges in the Religious Court to facilitate the examination and resolution of Islamic economic disputes. Whereas formal law for religious courts has explicitly not yet exist. During this time, the procedural law used is the procedural law that applies in the State Court, even though the types of cases that are under the authority of the Religious Court are not specific, which is not possible to solve using procedural law in the State Court. ${ }^{3}$

Further explanation of Article 49 of the UU-PA ${ }^{4}$ seems to place the Islamic economy as the central authority of the Religious Court. Whereas Islamic economics, is only part of the authority possessed by the Religious Court. Explanation of the authority of the Religious Court is further elaborate and explained in various fields starting from the letter (a) to letter (i).

Elucidation of Article 49 Letter (i) determines what is meant by "sharia economy" is an act or business activity carried out according to sharia principles, including but not limited to a. Islamic Bank; b. Sharia microfinance institutions; c. Sharia insurance; d. Sharia reinsurance; e. Sharia mutual funds; f. Sharia bonds and mediumterm sharia securities; g. Sharia securities; $h$. Sharia financing; i. Sharia pawnshop; j. Pension funds for sharia financial institutions; and k. Sharia business.

The mention of the 11 fields mentioned above, surely not a limitation because this preceded by the word 'among other things'; so it is certainly possible that outside the field there are other fields of Sharia economic activity. ${ }^{5}$ In the end, it is close to the sharia

in other sharia economics fields. (Islamic economics is only one of the authorities of the PA), although the following is also given a further explanation from letters a to letters $i$ as the authority of the Religious Court.

Diana Rahmi, 'Ruang Lingkup Kewenangan Peradilan Agama Dalam Mengadili Sengketa Ekonomi Syariah', (2013) 13(2) Jurnal Hukum dan Pemikiran, P.ISSN: 1412-6303, E.ISSN: 2549-001x $<$ https://jurnal.uinantasari.ac.id/index.php/syariah/article/view/174> accessed March 2020. 
business phrase, which, of course, is very open. Other sharia economic activities are complete in the Religious Court. It can interpret that the authority of the religious court related to the resolution of Islamic economic arguments is limited only in the scope of civil disputes. Islamic economic crime or offences remain the absolute authority of the State Court.

KHES as a material law consists of 4 books, namely:

1. Book I about Legal and Amwal Subjects;

2. Book II about the Covenant;

3. Book III about Zakad and Grant;

4. Book IV on Islamic Accounting

From the distribution of books in the KHES perspective, it can be understood that the legal relations (rechtsverhouding) of the parties regulated in Book II about the Covenant. A legal relationship in the form of a contract ${ }^{6}$ stated as an agreement between two or more parties to do or not do specific legal actions. Thus, the contract is an agreement that gave birth to a legal relationship because the agreement creates rights and obligations for the parties. For the fulfilment of promises that have ignored, forced efforts can be made to court or arbitration in the form of a breach of a tort, although basically settlement through the court is a last resort (ultimum remedium).

The legal relationship between the parties in sharia economic transactions begins with the contract. Violation of the contract can be addressed by litigation by submitting a breach of claim to the Religious Court. The exciting thing about KHES is that Book II regulates Covenant (Akad), but the contents in Chapter XV Article 391-412 found Gashb and Itlaf arrangements, which interpreted as deprivation and destruction. At first glance, the legal relationship between Gashb and Itlaf does not begin with an agreement that gave birth to a contract; it is even a single act and tends to be closer to a criminal offence. Therefore, it is necessary to study further whether this Gashb and Itlaf are following their placement in the KHES Book

See Article 20 number (1) of Book II of KHES Ahmad, 'Penyelesaian Sengketa Ekonomi Syariah di Pengadilan' (2014) II(6) Jurnal Hukum dan Keadilan, 482.
II, which regulates Akad, and determine whether Gashb and Itlaf are sharia economic activities. Furthermore, it is also necessary to determine the authority of the Religious Court in the settlement of Gashb and Itlaf.

Sharia economic disputes are very close to defaults. Ahmad ${ }^{7}$ delivered by taking a random decision on the final Religious Court related to Islamic economics from 2006 to 2013 totalling 20 cases. Eighteen of these cases constitute a type of dispute in breach of contract, and the other two are for removal, namely the removal of the Basyarnas decision and cancellation of the musyarakah financing auction.

There are quite a lot of studies that discuss the authority of the Religious Court related to sharia economics. In general, what have investigated are the fields of sharia economics under the authority of the Religious Court. No studies have found that have specific discussions on Gashb or Itlaf related to sharia economic disputes.

Based on the explanation presented above, it is necessary to study further the legal relationship and arrangement of Gashb and Itlaf in KHES Book II and determine the settlement through the court by examining the elements and authority of the Religious Court in Indonesia. The problems are focused on: first, are Gashb and Itlaf a sharia economic activity that starts from the contract as specified in the second book of KHES? Second, Which court is authorized to settle Gashb and Itlaf?

\section{LEGAL MATERIALS AND METHODS}

To discuss the issues raised, a normative $^{8}$ juridical study carried out on the principles, harmonious and contractual terms, the concept of legal relations, and comparing Gashb and Itlaf with the provisions of Book III of the Civil Code on Commitments and Court authority. Presentation of information sourced from secondary data, with the use of primary legal material in the form of Law No. 3 of 2006

\footnotetext{
8 Soerjono Soekanto dan Sri Mamudji, Penelitian hukum Normatif Suatu Tinjauan Singkat, (Raja Grafindo Persada, Jakarta, 2009) 14.
} 
concerning Amendment of Law No. 7 of 1989 concerning Religious Court (UU-PA), Law No. 21 of 2008 concerning Sharia Banking, Supreme Court Regulation (Perma) No. 2 of 2008 concerning the Compilation of Sharia Economic Law, in particular, Book II on Covenants, and the Civil Code (BW) Book Specifically book III on Commitments.

The secondary legal materials used in this study sourced from various related articles, various books that discuss sharia economics, about engagement and other scientific products in the form of articles both print and online media. Tertiary material is material that seeks an explanation of primary and secondary legal materials. Data analysis uses a qualitative approach in-depth and overall and is simultaneous and holistic.

\section{RESULTS AND DISCUSSIONS}

\section{Gashb and Itlaf in KHES}

The legal principle of Ubi societas ibi ius, where there is a society there is a law, is appropriate to state the existence of Islamic law in Indonesia related to sharia economic activities. Furthermore, it can be said that where there are Muslim societies, Islamic Law applies there. According to the Elucidation of Article 49 letter (i) of Law No. 3 of 2006 determining the Islamic economy is an act or business activity carried out according to Islamic principles. The principle of sharia is an Islamic economic system that is based on Allah's guidance in the Al Qur'an, which is known by Muslim scholars as to the doctrine of non-usury transactions. ${ }^{9}$ Islamic economic activities avoid prohibited activities. ${ }^{10}$ The factors cause the cause of a prohibited transaction: ${ }^{11}$

a. The substance is haram (haram lidzatihi);

b. Other than its substance is haram (haram li-ghairihi);

9 M. Dawam Rahardjo, Pengantar dalam Adiwarman Karim, Bank Islam, Analisis Fiqih dan Keuangan, (PT. Rajagrafindo Persada, 4th Ed, Jakarta, 2010), xii

10 Zainuddin Ali, Hukum Perbankan Syariah, (Sinar Grafika, $2^{\text {nd }}$ Ed, Jakarta, 2010), 20.

11 Adiwarman Karim, Bank Islam, Analisis Fiqih dan Keuangan, (PT. Rajagrafindo Persada, $4^{\text {th }}$ Ed, Jakarta, 2010), 30. c. The contract is uncompleted.

Islamic economic law relations generally begin with the contract. Arrangement of contract for sharia economy has contained in Book II of KHES. The existence of KHES has intended as a guide for Religious Court judges in examining and deciding economic disputes according to sharia principles. KHES content arranged in 4 (four) books as a large group with 796 articles. Of the four books referred to, Book I regulate the Subject of Law and Amwal, which consists of 19 articles, Book II regulates the Covenant with the most content, which amounts to 655 articles. Book III on Zakat and Grants consists of 60 articles, and Book IV on Sharia Accounting totalling 62 articles.

The most substantial part of the KHES content regulates the contract contained in Book II with the division of Chapters totalling 29 and 655 articles. Book II KHES have seen as describing the legal relationship originating from a contract and deeds or business activities based on sharia principles as referred to in Article 49 letter (i) of Law No. 3 of 2006. When observed, KHES contains legal material content. Material law has interpreted as a law that gives rights and burdens obligations as a basis for those who carry out Islamic economic transactions.

\section{a. Akad}

In Islamic law, the agreement is called an agreement that originates from Arabic $\mathrm{Al}$ Aqd, which means binding or connecting. ${ }^{12}$ The essence of the agreement is not limited to what has stated, in the form of documents, but also which has made verbally. "At law, however, a contract is more than just documents." ${ }^{13}$ Understanding the contract in positive law in Indonesia today can be found, among others;

12 Ahmad Abu Al Fath, quoted by Syamsul Anwar, Hukum perjanjian Syariah (Studi tentang teori Aqad dalam Fikih Muamalat), (PT. Raja Grafindo Persada, Jakarta 2007), 68.

13 Benny S Tabalujan, Valerie Du Toit-Low, (Singapura Bisnis Law CommAsia Resources Pte Ltd, Singapore. 2003), 57 
1) Article 1 number 13 of Law No. 21 of 2008 concerning Islamic Banking; "A contract is a written agreement between a Sharia Bank or UUS and another party that contains the rights and obligations of each party following sharia principles.

2) Article 20 number 1 KHES; "A contract is a deal in an agreement between two or more parties to do or not do certain legal actions."

In Islamic law, to form a valid and binding contract, it must meet the terms and conditions of the contract as follows:

a) The parties (al 'aqidain);

b) Statement of will (shiqhat aqad);

c) The object of the contract (mahallul aqad);

d) The purpose of the contract (maudhu'al aqad)

\section{b. Gashb dan Itlaf}

Gashb and Itlaf have regulated in Chapter XV of Book II KHES, which consists of five parts. The first part is about the Pillars and Gashb Terms, namely from Article 391 to Article 401. The second part regulates the seizure of fixed objects, namely from Article 402 to Article 404. The third part is about seizing confiscated assets, namely Article 405 and 406. The fourth part is about Direct Destruction of Assets, namely from Article 407 to Article 410. Furthermore, the fifth part is the final part about Indirect Destruction of Assets, which have regulated from Article 411 to Article 412.

Chapter XV of KHES is entitled to Gashb and Itlaf. Gashb is interpreted as "deprivation", ${ }^{14}$ while the meaning of Itlaf is explicitly not found in Chapter XV. Nevertheless, in General Provisions of Article 20, number 16 of KHES, Itlaf is referred to as "destruction". Likewise, the fourth part of Chapter $\mathrm{XV}$ is titled destruction, so that Itlaf is interpreted as vandalism. This meaning is in line with what was conveyed by Wahbah Zuhaili. ${ }^{15}$ In Indonesian, Chapter XV of KHES is given the title of appropriation and destruction. The first part governs the pillars and conditions,

14 See Article 391 of KHES

15 Wahbah Zuhaili, Figih Imam Syafii, Mengupas Masalah Fighiyah Berdasarkan Al Qur'an dan but what is found in the pillars of Gashb. Explicitly, the arrangement regarding the Gashb terms is not found in KHES.

Pillars or elements of Gashb / appropriation are perpetrators of deprivation, victims of deprivation, spoiled assets, and deprivation. What has interpreted as an act of deprivation is to prevent the victim from using wealth, including denying the existence of wadi'ah bih. ${ }^{16}$ The KHES determines sanctions for perpetrators of seizure, as stated in Article 393, namely:

a. Must return the property that has been confiscated if the asset is still in its power;

b. All costs related to transportation-related to the surrender of the spoil are the responsibility of the perpetrators of the seizure;

c. Obliged to repair and or replace the damaged property that has been confiscated;

d. Obliged to replace the property that has been confiscated if the asset has been lost or has been transferred;

e. Substitution of assets can be done with the same assets or at a value.

Judging from the harmony, Gashb and Itlaf do not start with an agreement. Gashb and Itlaf are not a contract nor relations based on sharia principles. Gashb is a unilateral action, so it is not included as a transaction and also not an activity carried out with sharia principles. Sharia economics are actions or business activities carried out according to sharia principles. It can be said that Gashb and Itlaf do not meet the elements of sharia economic activities so it has not duly regulated in the Sharia Economic Law Compilation.

In general, Gashb and Itlaf can be matched with unlawful acts (Article 1365) of the Civil Code. The KHES determines sanctions as a form of responsibility for Gashb and Itlaf perpetrators, in the form of returning, repairing, or replacing damaged, bearing the costs of surrender, and paying the price of depreciation. Judging from the regulation of Gashb and Itlaf sanctions, they

Hadis, Vol 2, (Almahira Publishing, Jakarta, 2008), 253

16 Wadi'ah bih is an entrusted property. 
do not constitute an offence. If the perpetrator returns the spoils in the sense of surrendering the property that has been confiscated to the owner as of the victim of seizure, then the perpetrator has been freed from his responsibility. ${ }^{17}$

Article 397 KHES determines, "The perpetrators of deprivation have the right to complain to the (Religious) Court if the owner of the object refuses to accept the property that has confiscated." This provision is unusual, considering that the perpetrators complained to the court. ${ }^{18}$ Normally a complaint is submitted to the investigator by the victim, of course, to report the perpetrators' actions that are against the law. In Gashb and Itlaf, the perpetrators complained to the Religious Court. It would be more appropriate according to the law if the owner filed a claim for rights in the form of tort against the law by asking for compensation.

Compensation for damages can be done directly, through a mediator and or court. ${ }^{19}$ The direct causes of damage or depreciation in the value of assets must be held responsible. The judge has the right to decide about the perpetrators who are responsible if two indirect causes cause damage or depreciation. ${ }^{20}$

It has seen that seizure or vandalism activities are related to material rights. The Gashb and Itlaf cannot start with an agreement because an agreement requires permission and qabul. When the Gashb and Itlaf have declared as a contract, associated with the provisions of Article 1320 of the Civil Code regarding the validity of the agreement, especially paragraphs (3) and paragraphs (4), inevitably the agreement becomes null and void because the Gashb and Itlaf as the object of the agreement are contrary to the law, so the agreement is initially considered never exist.

It should have emphasized that Gashb and Itlaf are unilateral actions. They are outside the contract and do not include

17 See Article 395 and Article 396, as well as Article 398 of KHES

18 Article 1 number 8 of KHES determines that the Court is a syar'iyah court / within the religious court environment.
Islamic economic activities. Sharia economic activities have limited by the Elucidation of Article 49 letter (i) of the UU-PA. Precisely the existence of Gashb and Itlaf is an act that is not following Islamic principles because it causes loss and damage to others. Thus, the Gashb and Itlaf need not regulated in the Compilation of Sharia Economic Law.

When compared with the provisions in the Criminal Code, Gashb and Itlaf are not threatened with criminal penalties as regulated in Article 10 of the Criminal Code. The use of the term perpetrators and victims in Gashb seems to make it an offence. Deprivation in the provisions of the Criminal Code regulated in Article 368, which reads whosoever intends to benefit oneself or others unlawfully, forcing a person with violence or threat of violence, to give away something, which is wholly or partly have owned by that person or another person. Falling in the Criminal Code has regulated in Article 406 to 412. Destruction can be intentional or unintentional. Destruction as an act against the right can mean destroying, making it unable to function, or eliminating other people's belongings in whole or in part. The act of falling, according to the Criminal Code, is threatened with imprisonment or fines, while the destruction in the context of Gashb and Itlaf has threatened with claims for compensation for losses suffered. In the Criminal Code, intentional or negligent acts have different criminal threats. Whereas in Gashb and Itlaf, the damage done intentionally or due to negligence has the same form of responsibility, i.e., with compensation. Thus, Gashb and Itlaf are not interpreted as an offence even though there is the phrase taking or damaging someone else's property without permission and without intending to own it.

Although the classification used is deprivation and destruction, the KHES does not contain provisions on Islamic economic crime because it has intended as a guide for judges in the Religious Court in resolving

19 See Article 411
$20 \quad$ See Article 412 
Islamic economic disputes with civil disputes. Therefore, Gashb and Itlaf can be equated with the Act of Violating the Law as determined by Article 1365 of the Civil Code (onrechtmatege daad).

\section{Authority of the Religious Court Regarding Gashb and Itlaf}

The Religious Court is one of the judicial environments under the Supreme Court in the justice system in Indonesia. The Religious Court was formally legally first based on Law No. 7 of 1989, which has intended for people who are Muslim. Initially, the authority of the Religious Court was limited only to certain civil cases, especially family law. With Law No. 3 of 2006, there was a change to Law No. 7 of 1989, which gives more room for divine justice. $^{21}$ Expansion by adding absolute competence to divine justice is not only limited to Islamic family law but also sharia economic transactions.

The expansion of authority is following the development of the law and the needs of the community, especially the Muslim community. As expressed, Eugen Ehrlich ${ }^{22}$ that good law is a law that is following the law that lives in society (living law). Ehrlich also stated that positive law would only be accurate if it is in harmony with the law that lives in society.

The Islamic economic case, which becomes the authority of the Religious Court, is found in Article 49 letter (i). Elucidation of Article 49 letter (i): "Sharia economy is defined as actions or business activities carried out according to sharia principles, including sharia banks, sharia insurance, sharia reinsurance, sharia mutual funds, sharia bonds and sharia medium-term securities, securities sharia, sharia financing, sharia pawnshops, pension funds of sharia financial institutions, sharia businesses and sharia microfinance institutions." The authority of the Religious Court in resolving Islamic economic disputes is not limited, as

21 Tuti Haryanti, 'Kewenangan Peradilan Agama Dalam Penyelesaian Sengketa Ekonomi Syariah' (2013) IX(1) Jurnal Tahkim, 77

22 Soerjono Soekanto, Pokok-Pokok Sosiologi Hukum, (PT. Rajagrafindo Persada, Jakarta, 2005), stated in Article 49 (i). With the phrase "sharia business", sharia economic disputes that develop in society can still be accommodated like digital financial disputes. Although not explicitly mentioned in Article 49 (i).

Moreover, according to the principle, a judge is prohibited from rejecting a case, under the pretext that the law is absent or unclear. ${ }^{23}$ Islamic economic disputes as the absolute authority of the Religious Court based on Article 49 letter (i) of Law no. 3 of 2006 and strengthened by the Constitutional Court with Decision No.93 / PUU-X / 2012, dated August 29, 2013. Thus, related to Islamic economic disputes, there is no debate related to the authority of the Religious Court. Other courts outside the Religious Court is not authorized to settle Islamic economic disputes. Nevertheless, related to offences or criminal acts in sharia economics such as embezzlement, fraud, and others remain the authority of the General Judiciary. Islamic economic matters which become the authority of religious courts are only limited to civil matters.

The implementation of Islamic economic transactions has the potential to cause conflict between the parties. Conflicts occur because of discrepancies between one party and another party. The source of the conflict can originate from the agreement when one party does not fulfil what was initially agreed upon, which is legal language is often called a default. Civil cases submitted to the Religious Court has formulated in the form of a lawsuit or petition. Sharia economic disputes in the Religious Court can be formulated in the form of breach of contract violations or the form of tort against the law.

On the other hand, a dispute can also start with an act that violates the law, that is, an act that meets the criteria of Article 1365 of the Civil Code, that is, every act that carries a loss to another person, obliges the person who due to wrongly issued the loss to

42. See Article 10 paragraph (1) Law No. 48 of 2009 concerning Judicial Power. 
replace it. Four things must have fulfilled for illegal acts, namely:

a. The element of action (positive or negative);

b. There is an error;

c. Causing loss;

d. There is a causal relationship between actions and losses incurred.

The settlement of economic disputes by litigation is usually in the form of claims for compensation, which are requested to fulfill through a breach of a lawsuit or a violation of the law. A breach of a claim that must be proven is that the legal relationship between the parties begins with a contract/agreement. In the context of KHES, for a contract to be legally binding, the contract must meet the terms and conditions of the contract.

The Pillars (elements) of a contract consist of; Contracting parties, an object of the contract, the primary purpose of the contract, and the agreement. An agreement is invalid if it conflicts with:
a. Islamic Sharia;
b. Laws and regulations;
c. Public order and/or
d. Decency.

Provisions of Civil Code Book III regulates engagement (van verbintenissen). The engagement has understood as a legal relationship (rechtsverhouding) in the field of property law. According to the doctrine, an engagement is a legal relationship that occurs between two or more parties, which located in the field of property law, where one party is entitled to achievement, and the other party is obliged to fulfil that achievement. ${ }^{24}$ The engagement breeds related rights, which is the right to demand fulfilment only to the opposing party with whom the legal relationship has formed. ${ }^{25}$ According to Article 1233 of the Civil Code, each engagement is born either because of an agreement or the law. One of the agreements that were born because of the law is an illegal

24 Mariam Darus Badrulzaman, et.al, Kompilasi Hukum Perikatan (in order to Embrace the Purna Bakti 70 Years Age), (Citra Aditya Bakti, Bandung, 2001), 1. Lihat juga Riduan Syahrani, Seluk Beluk dan Asas-Asas Hukum Perdata, (Alumni Bandung, $\left.2^{\text {nd }} E d, 2004\right), 196$. act (onrechtmatige daad) that the agreement (contract) must give birth to a legal relationship, namely the existence of rights and obligations for the parties.

In addition to legal agreements (contracts) also arise because of the law. The legal relationship that was born due to the law was caused by human actions, both according to law or violate the law (Dutchonrechtmatige daad, English-Tort). Unlawful acts have interpreted as acts in the civil field. Violations in the civil field, with sanctions as a form of responsibility, is in the form of compensation payments.

According to the Provisions of Book III of Civil Code, if the articles do not contradict the sharia principles also apply to sharia economics. Thus, acts in the form of Gashb and Itlaf, including acts that violate the law that cause the obligation for perpetrators to compensate following Article 1365 of the Civil Code.

According to Ahmad Mujahidin, ${ }^{26}$ Islamic economic disputes can be classified into three (three), namely:

a. Disputes in the field of Islamic economics between financial institutions and Islamic financial institutions and their customers;

b. Disputes in the field of Islamic economics between financial institutions and Islamic financial institutions;

c. Disputes in the field of sharia economics between people who are Muslims in which the agreement is explicitly stated that the business activities carried out have based on sharia principles.

Judging from the competence provided by the UU-PA, specifically Article 49, the authority of the Religious Court is tasked with and has the authority to examine, decide upon, and settle cases at the first level among people who are Muslims in the fields of: a. marriage; b. inheritance; c. will; d. grant; e. waqf; f. zakat; g. infaq; h. Sadaqah; and i. Islamic economy.

25 See Abdulkadir Muhammad, Hukum Perdata Indonesia, (Citra Aditya Bakti, 3th Ed, Bandung, 2000) 134

26 Ahmad Mujahidin, Prosedur Penyelesaian Sengketa Ekonomi Syariah di Indonesia, (Ghalia Indonesia, Bogor, 2010) p 43 
The UU-PA has specifically limited cases which are the absolute authority of the Religious Court. Sharia economic disputes which become the authority of the religious court have also explicitly been determined, as specified in the Elucidation of Article 49 letter (i), although not limited in nature. If seen Gashb and Itlaf as discussed earlier, it does not include Islamic economic activities, because it is not included in the economic system doctrine that forbids usury. Gashb and Itlaf are actions or activities that cause loss and damage, but in substance do not include Islamic economic activities.

A lawsuit for violating Islamic economic law, based on Article 49 of the UU-PA, is the absolute authority of the religious court. However, because the Gashb and Itlaf have not included in any act or business activity carried out according to sharia principles, the settlement of the Gashb and Itlaf is not included as the absolute authority of the religious court. Claims for damages due to Gashb and Itlaf can be filed with compensation through lawsuits against unlawful acts submitted to the State Court.

The elements of unlawful acts on Gashb and Itlaf, as intended by Article 1365 of the Civil Code, have been fulfilled. Thus, the Gashb and Itlaf perpetrators can be sued by the owner to return his property that is damaged, reduced, or lost. According to Article 411 KHES, claims for the return and replacement of assets can be made directly, through mediators or the Religious Court. However, when seen from the authority of the Religious Court granted by the Elucidation of Article 49 letter (i), then Gashb and Itlaf should not be included in the absolute authority of the Religious Court.

Law No. 48 of 2009 concerning Judicial Power in the preamble section states that judicial power has tasked with administering justice to uphold law and justice. In the case of dispute resolution, the judge has tasked with carrying out the function of passing on judicially, by

27 See Wirjono Prodjodikoro, Asas-asas Hukum Perjanjian, (Sumur Bandung, $7^{\text {th }}$ Ed, Jakarta, 1973), 13

28 Retnowulan Sutantio and Iskandar Oeripkartawinata, Hukum Acara Perdata Dalam examining the lawsuit by examining the evidence submitted by the plaintiff and the defendant then gives his decision.

The authority of the court in examining a lawsuit is to assess whether the legal relationship that occurs has fulfilled the legal elements, as the basis for the plaintiff's claim, so that the claim can be granted, be rejected, or unaccepted. The claim is granted or rejected depending on how the plaintiff and the defendant prove the claim or rebuttal and denial of the legal relationship and the existence of rights and obligations between the parties. Errors in formulating potential lawsuits are not acceptable (niet ontvankelijk verklaard / NO). A lawsuit becomes NO because it does not meet formal requirements according to legal provisions and legislation.

In the Fundamentum Petendi, what must have explained and proven is the act or event of appropriation by the offender with the petitum of return and request for compensation. Thus, the legal relationship is a relative right which can only be sued to the perpetrator, and in fact, does not constitute Islamic economic activity. The implementation of procedural law has based on actiones in personam, which can only file against certain people, ${ }^{27}$ namely the perpetrators. Because it is not a sharia economic activity, the court in absolute authority is not a Religious Court. The authority to settle the Gashb and Itlaf is in the general court environment. Efforts should be made so that the lawsuit is not submitted incorrectly, ${ }^{28}$ related to the authority to judge both absolutely and relatively. In the case of filing a lawsuit, the plaintiff must pay attention that the lawsuit was filed appropriately related to several aspects, namely absolute authority, and the relative authority of the court. Besides, it must also have considered precisely the fundamental legal relations of the parties, whether as an agreement (contract) or as an unlawful act. Unlawful acts, according to Islamic law, are al-fi'lu al-dharr (harmful acts). ${ }^{29}$

Teori dan Praktek, (Mandar Maju, 9 ${ }^{\text {th }}$ Ed, Bandung, 2002), 11.

29 Ahmad Mujahidin, above n 26, 45 
According to M. Yahya Harahap, ${ }^{30}$ there is a tendency for the practice to demand a precise formulation of the lawsuit between the fundamentals of the petendi (posita) and the petitum according to the dagvaarding/lawsuit system (regulated in Article 1 RV (Reglement of de Rechtsvordering Staatblaad 1847 - 52 Jo. 1849 - 61). The basis of the lawsuit must be clear without any doubt about the legal relationship that will be requested fulfilment. The Fundamentum Petendi is the basis of the examination for the assembly to resolve and decide upon disputes, as well as determine the burden of proof on the plaintiff to prove the arguments of the lawsuit, as determined by Article 1865 of the Civil Code and Article 163 of HIR (Herzien Inlandsch Reglement). The article confirms that everyone who postulates a right or to confirm their rights or deny the rights of others is required to prove the rights or events (Actori incumbit onus probandi).

Related to lawsuits in filing a lawsuit against Gashb and Itlaf, if it has filed in a religious court, the assembly should have stated that the claim cannot be accepted because it is the absolute authority of the general court.

\section{CONCLUSION}

Gashb and Itlaf do not include relationships based on sharia principles. Thus, Gashb and Itlaf are not Islamic economic activities and have not based on contracts. Elucidation of Article 49 letter (i) of Law no. 3 of 2006 concerning Religious Court determines that sharia economy is an act or business activity carried out according to sharia principles while Gashb and Itlaf do not belong to the economic system and even acts that tend to cause loss and damage. Gashb and Itlaf, which cause loss and damage, can be prosecuted based on lawsuits in violation of the law in public justice. Acts violating Islamic economic law are the absolute authority of the religious court. However, because Gashb and Itlaf are not legal relations based on sharia principles, they are not automatically included in the absolute authority of religious courts. The court that has the authority to settle it is the State Court.

Considering that Gashb and Itlaf are not relationships based on sharia principles and not Islamic economic activities, they should not have regulated in the KHES. As for the settlement of Gashb and Itlaf, they should have excluded from KHES. If there are lawsuits against the law relating to Gashb and Itlaf submitted to the Religious Court, the judge should decide with an unacceptable suit (Niet Ontvankelijke verklaard).

\section{REFERENCES}

\section{Books}

Ali, Zainuddin, Hukum Perbankan Syariah, (Sinar Grafika, 2nd Ed, Jakarta, 2010). Anwar, Syamsul, Hukum perjanjian Syariah (Studi tentang teori Aqad dalam Fikih Muamalat), (PT. Raja Grafindo Persada, Jakarta 2007).

Badrulzaman, Mariam Darus et.al, Kompilasi Hukum Perikatan (in order to Embrace the Purna Bakti 70 Years Age), (Citra Aditya Bakti, Bandung, 2001)

Harahap, M. Yahya, Hukum Acara Perdata tentang Gugatan, Persidangan, Penyitaan, Pembuktian dan Putusan Pengadilan, (Sinar Grafika, $8^{\text {th }}$ Ed, Jakarta, 2008).

Karim, Adiwarman, Bank Islam, Analisis Fiqih dan Keuangan, (PT. Rajagrafindo Persada, 4th Ed, Jakarta, 2010)

Marzuki, Peter Mahmud, Pengantar Ilmu Hukum, (Kencana Prenada Media Grup, Jakarta 2009).

Muhammad, Abdulkadir, Hukum Perdata Indonesia, (Citra Aditya Bakti, 3th Ed, Bandung, 2000).

Mujahidin, Ahmad, Prosedur Penyelesaian Sengketa Ekonomi Syariah di Indonesia, (Ghalia Indonesia, Bogor, 2010).

Prodjodikoro, Wirjono, Asas-asas Hukum Perjanjian, (Sumur Bandung, $7^{\text {th }}$ Ed, Jakarta, 1973).

30 M. Yahya Harahap, Hukum Acara Perdata tentang Gugatan, Persidangan, Penyitaan, Pembuktian 
Soekanto, Soerjono and Sri Mamudji, Penelitian hukum Normatif Suatu Tinjauan Singkat, (Raja Grafindo Persada, Jakarta, 2009).

Soekanto, Soerjono, Pokok-Pokok Sosiologi Hukum, (PT. Rajagrafindo Persada, Jakarta, 2005).

Sutantio, Retnowulan and Iskandar Oeripkartawinata, Hukum Acara Perdata Teori dan Praktek, (Mandar Maju Publishing, $9^{\text {th }}$ Ed, 2002).

Syahrani, Riduan, Seluk Beluk dan Asas-Asas Hukum Perdata, (Alumni Bandung, $2^{\text {nd }}$ Ed, 2004).

Tabalujan, Benny S, Valerie Du Toit-Low, (Singapura Bisnis Law CommAsia Resources Pte Ltd, Singapore. 2003)

Zuhaili, Wahbah, Figih Imam Syafii, Mengupas Masalah Fighiyah Berdasarkan Al Qur, an dan Hadis, Vol.2, (Almahira Publishing, Jakarta, 2008).

\section{Journal}

Ahmad, 'Penyelesaian Sengketa Ekonomi Syariah di Pengadilan' (2014) II(6) Jurnal Hukum dan Keadilan,.

Domiri, 'Analisis Tentang Sistem Peradilan Agama di Indonesia', (2016) 47(43) Jurnal Hukum dan Pembangunan, 334, (ISSN: 0125-9687 (Print) E-ISSN: 2503-1465 (Online))
Haryanti, Tuti, 'Kewenangan Peradilan Agama Dalam Penyelesaian Sengketa Ekonomi Syariah' (2013) IX(1) Jurnal Tahkim.

Rahmi, Diana, 'Ruang Lingkup Kewenangan Peradilan Agama Dalam Mengadili Sengketa Ekonomi Syariah', (2013) 13(2) Jurnal Hukum dan Pemikiran, P.ISSN: 1412-6303, E.ISSN: 2549001x <https://jurnal.uinantasari.ac.id/index.php/syariah/article /view/174> accessed March 2020.

\section{Law}

Kitab Undang-Undang Hukum Perdata

Kitab Undang-Undang Hukum Pidana

Undang-Undang No 7 Tahun 1989, yang telah diubah dengan Undang-Undang No, 3 Tahun 2006, dan perubahan kedua dengan Undang-Undang No 50 Tahun 2009 tentang Peradilan Agama

Undang-Undang 21 Tahun 2008 tentang Perbankan Syariah

Undang-Undang No. 48 tahun 2009 tentang Kekuasaan Kehakiman

Peraturan Mahkamah Agung No. 2 tahun 2008 tentang Kompilasi Hukum Ekonomi Syariah 